\title{
Characterization of the retained sludge in a down-flow hanging sponge (DHS) reactor with emphasis on its low excess sludge production
}

\author{
Takashi Onodera $^{1,2} \dagger^{*}$, Kengo Matsunaga ${ }^{1,3} \dagger$, Kengo Kubota $^{3}$, Ryoko Taniguchi ${ }^{3}$, \\ Hideki Harada ${ }^{3}$, Kazuaki Syutsubo ${ }^{2}$, Tsutomu Okubo ${ }^{4}$, Shigeki Uemura ${ }^{4}$, Nobuo Araki ${ }^{5}$, \\ Masayoshi Yamada ${ }^{6}$, Masahito Yamauchi $^{6}$, Takashi Yamaguchi ${ }^{1}{ }^{*}$ \\ ${ }^{1}$ Department of Civil and Environmental Engineering, Nagaoka University of \\ Technology, 1603-1 Kamitomioka, Nagaoka, Niigata 940-2188, Japan \\ ${ }^{2}$ Center for Regional Environmental Research, National Institute for Environmental \\ Studies, 16-2 Onogawa, Tsukuba, Ibaraki 305-8506, Japan \\ ${ }^{3}$ Department of Civil and Environmental Engineering, Tohoku University, 6-6-06 Aoba, \\ Aramakiaza, Aoba-ku, Sendai 980-8579, Japan \\ ${ }^{4}$ Department of Civil Engineering, Kisarazu National College of Technology, 2-11-1 \\ Kiyomidaihigashi, Kisarazu 292-2188, Japan \\ ${ }^{5}$ Department of Civil Engineering, Nagaoka National College of Technology, 888, \\ Nishi Katagai, Nagaoka, Niigata 940-8532, Japan \\ ${ }^{6}$ Department of Urban Environmental Design and Engineering, Kagoshima National \\ College of Technology, 1460-1 Shinkou Hayato, Kirishima, Kagoshima 899-5193, \\ Japan \\ $\uparrow$ Two authors contributed equally to this work. \\ *Corresponding authors
}

T. Onodera (E-mail: onodera.takashi@nies.go.jp; Tel: +81-29-850-2412; Fax: $+81-29-850-2569)$

T. Yamaguchi (E-mail: ecoya@vos.nagaokaut.ac.jp; Tel/Fax: +81-258-47-9612) 


\begin{abstract}
Experiments to characterize retained sludge in a down-flow hanging sponge (DHS) reactor fed with upflow anaerobic sludge blanket (UASB) treated sewage under moderate conditions were conducted. Plenty of oxygen was supplied through the DHS reactor without aeration and the effluent qualities after the reactor were comparable to activated sludge processes. The average excess sludge production rate was $0.09 \mathrm{~g} \mathrm{SS}$ $\mathrm{g}^{-1}$ COD removed. The DHS reactor maintained a high sludge concentration of $26.9 \mathrm{~g}$ $\mathrm{VSS} \mathrm{L}^{-1}$ sponge, resulting in a low loading rate of $0.032 \mathrm{~g} \mathrm{COD} \mathrm{g}^{-1} \mathrm{VSS} \mathrm{day}^{-1}$. The endogenous respiration rate of DHS sludge was comparable to previously reported aerobic sludges. The numbers of microfauna were one order of magnitude greater than those in activated sludge. The results indicated that low excess sludge production was attributable to the high sludge concentration, sufficient oxygen supply, adequate endogenous respiration rate, and a high density and diversity of microfauna.
\end{abstract}

Keywords: Sewage, low excess sludge, down-flow hanging sponge (DHS), microfauna 


\section{Introduction}

The activated sludge process is one of the most widely applied biological sewage treatment processes, despite the production of a large amount of excess sludge.

Disposal of the excess sludge is an important issue in wastewater treatment plants because of the huge treatment cost, limitation of disposal fields, and public perception. To save costs in excess sludge management, it is preferred to reduce sludge production during wastewater treatment processes rather than using additional sludge treatment processes.

Considering metabolic mechanisms, anaerobic treatment processes have great potential to reduce the excess sludge production compared with aerobic treatment processes (McCarty, 1964). Recently, upflow anaerobic sludge blanket (UASB) reactors have been used for sewage treatment, especially in tropical and sub-tropical regions, as a simple and low cost process (Sato et al., 2006; Kassab et al., 2010). Smaller amounts of well-stabilized sludge are produced by the UASB process compared with the activated sludge process (Lettinga et al., 1983; Takahashi et al., 2011). However, UASB treated sewage needs post-treatment because its water quality usually does not satisfy regulations for discharge into environments (Sato et al., 2006).

Many processes have been applied as post-treatment processes for UASB treated municipal sewage (Kassab et al., 2010). An attractive process is the down-flow hanging sponge (DHS) process (Machdar et al., 2000; Tawfik et al., 2006; Tandukar et al., 2006; Tandukar et al., 2007). The configuration of the DHS process is similar to that of the trickling filter. The wastewater is trickled from the top of the vessel filled with polyurethane sponge media and is treated by sludge retained in the sponge media. The sewage flows vertically down each sponge in the reactor by gravity. Oxygen is 
naturally supplied to the sewage from the atmosphere because the sponge media are exposed to the air. The DHS process shows high organic removal efficiency and high nitrification efficiency. Its effluent water is similar to an activated sludge process and satisfies adequate levels for discharge (Tandukar et al., 2007). The retained sludge concentration of the DHS process is 5-10 times greater than that in activated sludge (Tandukar et al., 2005). Moreover, pilot scale experiments have shown much lower amounts of excess sludge during long experimental periods (Tandukar et al., 2005; Tandukar et al., 2007). However, the retained sludge characteristics in the DHS process have not been comprehensively evaluated so far.

The aim of this study is to evaluate the sludge characteristics of a DHS reactor, from which very low excess sludge is produced. The DHS reactor was fed with UASB treated municipal sewage for more than 2 years under moderate climate conditions and the process performance and excess sludge production were continuously monitored. The retained sludge concentrations, endogenous respiration rates, and microfauna populations were investigated and the changes in the water quality and sludge characteristics along the height of the DHS reactor were also evaluated.

\section{Methods}

\subsection{Reactor configurations}

A UASB and DHS combined system (UASB-DHS system) was operated under ambient temperatures ranging from 10 to $32^{\circ} \mathrm{C}$ at a municipal sewage treatment plant in Nagaoka, Japan (Fig. S1). A cylindrical UASB reactor with a height of $4.0 \mathrm{~m}$ and a 
working volume of 1,148 L, including a gas solid separator (GSS), was employed as an anaerobic pre-treatment process. The DHS reactor consisted of 10 segments connected vertically, and was randomly filled with sponge media as the packing material. A distributor was set at the top of the DHS reactor to feed UASB effluent in. The DHS reactor volume (vessel volume) and the sponge media volume were $857 \mathrm{~L}$ and $454 \mathrm{~L}$, respectively, which corresponds to a sponge media occupancy of 53\%. The sponge media was a polyurethane sponge cube $(33 \mathrm{~mm})$ packed inside a cylindrical plastic net ring (33 mm diameter, $33 \mathrm{~mm}$ length). The void ratio of the sponge was more than $97 \%$ and the average pore size of the sponge was $0.63 \mathrm{~mm}$. The sponge media volume was calculated based on a cylindrical shape. A clarifier was set at the bottom of the DHS reactor with a working volume of $32.5 \mathrm{~L}$.

\subsection{Operating conditions}

The settled sewage obtained from the sewage treatment plant was fed to the UASB reactor by using a peristaltic pump. The UASB effluent was distributed from the top of the DHS reactor and flowed down through the sponge media by gravity. The DHS effluent was discharged from the clarifier. The hydraulic retention time (HRT) of the UASB reactor and the DHS reactor based on the sponge media volume were $8.0 \mathrm{~h}$ and $3.2 \mathrm{~h}$, respectively. The UASB reactor was started up with inoculation of the digested sewage sludge 76 days before the DHS reactor operation started. The DHS reactor was started up using sponge media without inoculation and operated without sponge replacement or sponge washing during the entire operational period of approximately 850 days. 


\subsection{Water quality analysis}

The routine analysis was continuously performed twice a week. The sewage and the UASB effluent were obtained by $24 \mathrm{~h}$ composite sampling ( 5 min every h) and samples were stored in tanks at $4^{\circ} \mathrm{C}$. The DHS effluent was obtained by grab sampling. Temperature, $\mathrm{pH}$, oxidation-reduction potential (ORP), and dissolved oxygen (DO) in the samples were obtained by grab sampling and measured on site. The $\mathrm{pH}$ and ORP were analyzed using a pH meter (HM-12P, TOA DKK, Japan) and an ORP meter (PTS-2019C, TOA DKK, Japan), respectively. Suspended solids (SS) and volatile suspended solids (VSS) were determined using a glass filter $(0.4 \mu \mathrm{m}$, GB140, ADVANTEC, Japan). The unfiltered samples were used to analyze biochemical oxygen demand (BOD), chemical oxygen demand (COD), and total Kjeldahl nitrogen (TKN). The filtered sample was used to determine filtered COD, ammonium, nitrate, and nitrite. The COD and TKN were analyzed by a HACH water quality analyzer (DR-2500, HACH, US) and nitrogen compounds were detected using HPLC (LC-10A Tvp, Shim-pack IC-C1, IC-A1, Shimadzu, Japan). Other water quality experiments were conducted according to AHPA (1998).

The settled (excess) sludge in the clarifier was sampled during the routine analysis and the SS and VSS were measured. The sludge volume index (SVI) was determined according to the Standard method (AHPA, 1998).

\subsection{Calculation of sludge retention time and sludge production rate}

The $\mathrm{SS}_{\text {sum }}$ production from the DHS reactor was defined as the sum of SS volumes in the DHS effluent and the excess sludge settled in the clarifier. The sludge retention 
time (SRT) and sludge production rate were determined according to Equations (1) and (2).

$$
\begin{aligned}
& S R T=\frac{V \times X_{\text {rea }}}{Q_{w} \times X_{w}+Q \times X_{\text {eff }}} \\
& Y_{o b s}=\frac{Q_{w} \times X_{w}+Q \times X_{e f f}}{Q \times C_{r e m}}
\end{aligned}
$$

Where SRT is the sludge retention time (day), V is the DHS reactor volume (sponge media volume) (L), $\mathrm{X}_{\text {rea }}$ is the retained sludge concentration in the DHS reactor (g SS $\mathrm{L}^{-1}$ sponge), $\mathrm{Q}_{\mathrm{w}}$ is the production volume of excess sludge $\left(\mathrm{L} \mathrm{day}^{-1}\right), \mathrm{X}_{\mathrm{w}}$ is the $\mathrm{SS}$ concentration of excess sludge $\left(\mathrm{g} \mathrm{SS} \mathrm{L}^{-1}\right), \mathrm{Q}$ is the flow rate $\left(\mathrm{Lday}^{-1}\right), \mathrm{X}_{\text {eff }}$ is the SS concentration in the DHS effluent $\left(\mathrm{g} \mathrm{SS} \mathrm{L}^{-1}\right), \mathrm{Y}_{\mathrm{obs}}$ is observed yield coefficient, corresponding to the $\mathrm{SS}_{\text {sum }}$ production rate from the DHS reactor, $\left(\mathrm{g} \mathrm{SS} \mathrm{g}^{-1} \mathrm{COD}\right.$ removed) and $\mathrm{C}_{\text {rem }}$ is the removed COD concentration in the DHS reactor $\left(\mathrm{g} \mathrm{COD} \mathrm{L}^{-1}\right)$.

\subsection{Retained sludge measurements}

To determine retained sludge concentration in the DHS reactor, three sponge media were randomly taken from each segment. The sponge media were immersed and squeezed in distilled water to elute the retained sludge until the sponge became clean. The SS and VSS were analyzed in the squeezed sludge samples and calculated based on the sponge media volume. 


\subsection{Endogenous respiration rate}

To measure the endogenous respiration rate, sponge media were taken from segments 1 , 4 , and 8 on day 624 . The sludge samples were washed with phosphate buffer saline (PBS) solution ( $\left.\mathrm{NaCl} 7.6 \mathrm{~g} \mathrm{~L}^{-1}, \mathrm{NaH}_{2} \mathrm{PO}_{4} 0.50 \mathrm{~g} \mathrm{~L}^{-1}, \mathrm{Na}_{2} \mathrm{HPO}_{4} 1.54 \mathrm{~g} \mathrm{~L}^{-1}\right)$. The sludge concentration was adjusted to $2-3 \mathrm{~g} \mathrm{VSS} \mathrm{L}^{-1}$ using PBS solution. The sludge was aerated for $6 \mathrm{~h}$ at $25^{\circ} \mathrm{C}$ to remove the remaining substrates before the experiment. The DO in the sludge with or without substrate was monitored to determine DO decrease rate at $25^{\circ} \mathrm{C}$ and was measured using an oxygen monitor (5300A, YSI, US) with a detector (5301, YSI, US). The endogenous respiration rate was obtained by the sludge concentration and DO decrease rate.

\subsection{Microfauna observation}

Sponge media was taken from segments 1,4 , and 8 of the DHS reactor between day 781 and day 785 and sludge samples were taken from it. A sample (10 $\mu \mathrm{L})$ was used for counting microfauna with a phase contrast microscope (DMBA310, Shimadzu, Japan) and arcellinida, ciliophora, rotifera, nematoda, oligochaeta and cladocera were counted. The microfauna was named according to the New Taxonomy database of the SWISS-PORT group (NEWT; Phan et al., 2003). The average numbers were calculated using triplicate counting results.

\section{Results and discussion}

\subsection{Process performance of the UASB-DHS system}


The performance of the UASB-DHS system was evaluated for approximately 850 days. A summary of the water quality is shown in Table 1 . The average values were calculated based on one year operation results after the retained sludge concentration became stable (day 446-810). The UASB reactor removed approximately $65 \%, 70 \%$, and $60 \%$ of the influent SS, COD (unfiltered COD), and BOD (unfiltered BOD), respectively. Because the UASB process is anaerobic, the value of TKN did not change. The removal of the remaining organic substances and nitrification were effectively carried out by the following DHS reactor. The final effluent quality was as follows: $\mathrm{SS}=12 \mathrm{mg} \mathrm{L}^{-1}, \mathrm{BOD}=7 \mathrm{mg} \mathrm{L}^{-1}, \mathrm{COD}=36 \mathrm{mg} \mathrm{L}^{-1}$, and $\mathrm{TKN}=3 \mathrm{mg} \mathrm{L}^{-1}$ on average. The value of total nitrogen was moderately reduced after the DHS reactor, suggesting occurrence of denitrification. The process performance of the DHS reactor was similar to those in previous studies (Machdar et al., 2000; Tawfik et al., 2006; Tandukar et al., 2006) and was comparable to that of the activated sludge process as found in the previous study by Tandukar et al. (2007).

Time courses of temperature, SS, and BOD for sewage, UASB effluent, and DHS effluent are shown in Fig. 1. The temperature ranged throughout the year from 10 to $28^{\circ} \mathrm{C}$. The SS and BOD concentrations in the UASB effluent oscillated during the operational period. In the DHS effluent, the SS concentration tended to increase during the early stage of temperature elevating periods (the beginning of spring), especially in the second year (day 550 to 650). Similar to the SS concentration, the COD concentration increased in this period (Fig. S2). On the other hand, the BOD concentration was maintained at a low level during the operational period, indicating that SS in the temperature elevating periods mainly consisted of low biodegradable organic substances.

The profile analysis of the wastewater stream along the height of the DHS 
performance, and also reduce excess sludge production from the DHS reactor.

\subsection{SS production from the DHS reactor}

The production rate of the excess sludge settled in the clarifier was only $0.09 \mathrm{~g} \mathrm{SS} \mathrm{g}^{-1}$ COD removed ( $0.07 \mathrm{~g} \mathrm{VSS} \mathrm{g}^{-1}$ BOD removed) for one year under the steady state (day 446-810). This rate was much lower than those of other UASB post-treatment processes of $0.37 \mathrm{~g} \mathrm{TS} \mathrm{g}^{-1}$ COD removed in a submerged aerated biofilter (Gonçalves et al., 1998) and 0.29-0.33 $\mathrm{g} \mathrm{VSS} \mathrm{g}^{-1}$ BOD removed in a rotating biological contactor (Castillo et al., 1997). The VSS/SS ratio of the excess sludge was 0.68 on average and the value was almost stable during the steady state. The SVI of the excess sludge was a sufficient level of $33 \mathrm{~mL} \mathrm{~g}^{-1} \mathrm{SS}$, indicating the sludge was well stabilized.

The $\mathrm{SS}_{\text {sum }}$ (the sum of SS in the DHS effluent and excess sludge) production rate from the DHS reactor was observed at $0.18 \mathrm{~g} \mathrm{SS} \mathrm{g}^{-1} \mathrm{COD}$ removed $(0.20 \mathrm{~g}$ VSS $\mathrm{g}^{-1} \mathrm{BOD}$ removed). The $\mathrm{SS}_{\text {sum }}$ production rate relied on the operational temperature, i.e., $0.32 \mathrm{~g} \mathrm{SS} \mathrm{g}^{-1} \mathrm{COD}$ removed below $15^{\circ} \mathrm{C}$ and $0.02 \mathrm{~g} \mathrm{SS} \mathrm{g}^{-1} \mathrm{COD}$ removed above $25^{\circ} \mathrm{C}$. In particular, the $\mathrm{SS}_{\text {sum }}$ production rate increased during the temperature elevating period (between day 550 and day 650), indicating that the $\mathrm{SS}_{\text {sum }}$ production rate was strongly affected by season.

\subsection{Retained sludge in the DHS reactor}

The change of retained sludge concentration in the DHS reactor during the entire operational period is shown in Fig. 2. The DHS reactor was initiated using virgin sponge media without inoculums. The retained sludge concentration gradually 
increased after the initiation and reached $24.7 \mathrm{~g} \mathrm{VSS} \mathrm{L}^{-1}$ sponge (38.5 $\mathrm{g} \mathrm{SS} \mathrm{L}^{-1}$ sponge) on day 446. Although the retained sludge concentrations after day 446 fluctuated, it was assumed that the retained sludge concentration became stable after day 446 . The average VSS and SS concentrations under steady state were $26.9 \mathrm{~g} \mathrm{VSS} \mathrm{L}^{-1}$ sponge and $39.6 \mathrm{~g} \mathrm{SS} \mathrm{L}^{-1}$ sponge, respectively. The retained sludge concentration in the DHS reactor was about 10 times higher than that in the activated sludge process. Despite the fact that the average volumetric OLR was $0.9 \mathrm{~kg} \mathrm{COD} \mathrm{m}^{-3}$ day $^{-1}$ based on the sponge media volume in the DHS reactor, this high sludge concentration provided a low COD-VSS loading rate of $0.03 \mathrm{~g} \mathrm{COD} \mathrm{g}^{-1} \mathrm{VSS}_{\text {day }}^{-1}$ on average under steady state. The low food to microorganisms $(\mathrm{F} / \mathrm{M})$ ratio can be a main reason for low excess sludge production in DHS reactors. The membrane bioreactor (MBR) with low F/M ratio showed limited sludge production (Chang et al., 2011). Low and Chase (1999) also pointed out that the sludge production in an activated sludge process can be reduced by $44 \%$ when a lower F/M ratio was achieved by increasing the biomass concentration from 1.7 to $10.3 \mathrm{~g} \mathrm{~L}^{-1}$.

Based on the amount of retained sludge and the $\mathrm{SS}_{\text {sum }}$ production from the DHS reactor, SRT can be calculated as >135 days. Similarly, a long SRT (95-125 days) in the DHS reactor was observed in a previous experiment (Tandukar et al., 2007). SRT is also an important factor for reducing excess sludge production from wastewater treatment processes (Troiani et al., 2011). For instance, the observed yield coefficient $\left(Y_{o b s}\right)$, corresponding to the $\mathrm{SS}_{\text {sum }}$ production rate, of activated sludge process with SRT of less than 6 days was 0.4-0.5 $\mathrm{g} \mathrm{MLSS} \mathrm{g}^{-1}$ COD removed (Yoon et al., 2004), but it can be reduced as low as $0.23-0.32 \mathrm{~g} \mathrm{MLSS}^{-1}$ COD removed in MBR with longer SRT of 20-40 days. The much longer SRT of >135 days in the DHS reactor may contribute to the low $Y_{o b s}$ of $0.18 \mathrm{~g} \mathrm{SS} \mathrm{g}^{-1} \mathrm{COD}$ removed. Under long SRT conditions 


\subsection{Endogenous respiration rate of the retained sludge}

The endogenous respiration rates of the sludge sampled on day 624 were measured. The endogenous respiration rate at $25^{\circ} \mathrm{C}$ was $0.179 \mathrm{~g} \mathrm{O}_{2} \mathrm{~g}^{-1} \mathrm{VSS}$ day ${ }^{-1}$ at $0.4 \mathrm{~m}$ from the inlet (segment 1), $0.029 \mathrm{~g} \mathrm{O}_{2} \mathrm{~g}^{-1} \mathrm{VSS} \mathrm{day}^{-1}$ at $1.6 \mathrm{~m}$ (segment 4), and $0.018 \mathrm{~g} \mathrm{O}_{2} \mathrm{~g}^{-1}$ VSS day $^{-1}$ at $3.2 \mathrm{~m}$ (segment 8) (Fig. S6). The endogenous respiration rate decreased toward the outlet of the reactor. This tendency was similar to OLR in the DHS reactor. Thus, the DHS sludge exposed to a higher organic concentration had a greater endogenous respiration rate. It was reported that the endogenous respiration rate was 0.046 to $0.052 \mathrm{~g} \mathrm{O}_{2} \mathrm{~g}^{-1} \mathrm{VSS} \mathrm{day}^{-1}$ at $22-24^{\circ} \mathrm{C}$ in a membrane bioreactor (Witzig et al., 2002) and 0.072 to $0.192 \mathrm{~g} \mathrm{O}_{2} \mathrm{~g}^{-1} \mathrm{VSS} \mathrm{day}^{-1}$ at $20^{\circ} \mathrm{C}$ in an activated sludge (Kristensen et al., 1992). The endogenous respiration rate of DHS sludge was comparable to those aerobic sludges.

The endogenous respiration rates strongly depended on temperature. Sludge taken from segment 1 especially showed a drastic shift upon temperature. The endogenous respiration rates at 10 and $15^{\circ} \mathrm{C}$ were only 0.018 and $0.027 \mathrm{~g} \mathrm{O}_{2} \mathrm{~g}^{-1}$ VSS day $^{-1}$, respectively, whereas those at 25 and $35^{\circ} \mathrm{C}$ were 0.179 and $0.368 \mathrm{~g} \mathrm{O}_{2} \mathrm{~g}^{-1}$ VSS $\mathrm{day}^{-1}$, respectively. The endogenous respiration rates of segment 1 at 25 and $35^{\circ} \mathrm{C}$ were similar to the COD-VSS loading rates of segment $1\left(0.26 \mathrm{~g} \mathrm{COD} \mathrm{g}^{-1} \mathrm{VSS}_{\text {day }}{ }^{-1}\right)$.

\subsection{Microfauna population in the retained sludge}

The numbers of the microfauna in the retained sludge taken from segments 1,4 , and 8 of the DHS reactor are presented in Fig. 4. A number of protozoa and metazoa were found in the DHS sludge. The microfauna population changed along the reactor height 
because of the different wastewater characteristics. The number of the protozoa in the DHS sludge from segment 1 was $>84,000$ individuals (ind.) $\mathrm{mL}^{-1}$ sponge for arcellinida and $>40,000$ ind. $\mathrm{mL}^{-1}$ sponge for ciliophora. The number of ciliophora decreased from the inlet to the outlet, and was only 19,500 ind. $\mathrm{mL}^{-1}$ sponge in segment 8 . In contrast, the number of arcellinida increased from the inlet to the outlet, with almost double $\left(164,900\right.$ ind. $\mathrm{mL}^{-1}$ sponge) found in segment 8 . It is known that arcellinida prefer low OLR conditions in the activated sludge. Hence, the lower portion of the reactor, where the OLR was low, was the preferred environment for arcellinida.

In addition, protozoa in activated sludge treating the same sewage as the UASB-DHS system were counted. The numbers were 1,200 ind. $\mathrm{mL}^{-1}$ for arcellinida and 4,400 ind. $\mathrm{mL}^{-1}$ for ciliophora. These values fit with the number of key protozoa found in activated sludge (approximately 4,000 ind. $\mathrm{mL}^{-1}$ ) by Zhou et al. (2006). Comparing the two sludges, the number of protozoa in the DHS sludge is one order of magnitude greater than that in the activated sludge. However, the population of protozoa in the DHS sludge based on the sludge weight (ind. $\mathrm{g}^{-1} \mathrm{SS}$ ) is comparable to that in the activated sludge. The reason for the great number of protozoa in the DHS reactor is attributed to its higher sludge concentration, which is about 5-10 times higher than that in activated sludge.

Various metazoa, known as slow growing microfauna, were also present in the DHS sludge. The numbers of metazoa in the DHS sludge in segment 1 were 1,600 ind. $\mathrm{mL}^{-1}$ sponge for rotifera, 1,700 ind. $\mathrm{mL}^{-1}$ sponge for nematoda, 900 ind. $\mathrm{mL}^{-1}$ sponge for oligochaeta, and 400 ind. $\mathrm{mL}^{-1}$ sponge for cladocera. In oligochaeta, Aeolosoma sp. and Nais sp. were mainly observed. The number of metazoa decreased from the inlet to the outlet. Metazoa are known predators of bacteria and protozoa, and are introduced to activated sludge to reduce the excess sludge production (Rensink and 
Rulkens 1997; Hellen et al., 2006; Liang et al., 2006; Huang et al., 2007; Wei et al., 2009; Khursheed and Kazmi, 2011). They are also known to improve sludge settling characteristics (Hellen et al., 2006; Wei et al., 2009). For instance, oligochaeta, which were present in the DHS sludge, are known to be one of the dominant species in the microbial ecosystem in sewage treatment processes (Rensink and Rulkens, 1997). They may contribute to sludge reduction by predation of other species such as bacteria and protozoa. It has been reported that the sludge reduction rates of the members of oligochaeta, Aeolosoma hemprichi and Tubifex tubifex, were determined as $0.8 \mathrm{mg}$ VSS mg ${ }^{-1}$ Aeolosoma day ${ }^{-1}$ and $0.54 \mathrm{mg} \mathrm{VSS} \mathrm{mg}^{-1}$ Tubifex day ${ }^{-1}$, respectively (Liang et al., 2006). The sludge production in a pilot activated sludge reactor treating settled domestic wastewater decreased from 0.40 to $0.15 \mathrm{~g} \mathrm{MLSS}^{-1}$ COD removed when Tubificidae (oligochaeta) were added to the aeration tank (Rensink and Rulkens, 1997). On the other hand, Luxmy et al. (2001) suggested that metazoa are not effective for reducing sludge production in an aeration tank and Liang et al. (2006) pointed out that the contradictory opinions were related to the lack of effective methods to determine sludge reduction rates caused by microfauna. Therefore, the development of an adequate evaluation method is important.

Worms were not totally counted, but there were many in the DHS sludge (Fig. S7). To reduce the excess sludge by microfauna predation, the use of worms has begun to receive increasing attention (Khursheed and Kazmi, 2011). Wei et al. (2003b) reported that the density of worms was negatively correlated to sludge yield. The operating conditions, such as DO concentration, are also important for sludge degradation by worms. Hendrickx et al. (2009) found that a high DO concentration was required to maintain the maximum sludge consumption rate by worms added to the reactor because a significant decrease in the number of worms under low DO 
concentration (below $1 \mathrm{mg} \mathrm{L}^{-1}$ ) environments was observed. Sufficient DO, supplied through the DHS reactor, enabled the growth of worms in the DHS sludge. In addition, sponge media might be the preferred environments for worms. It is likely that the worms contributed to the reduction of sludge production from the DHS reactor.

\section{Conclusion}

The DHS reactor showed high effluent quality and only $0.09 \mathrm{~g} \mathrm{SS} \mathrm{g}^{-1}$ COD removed of excess sludge was discharged. The DO, F/M ratio, SRT, endogenous respiration rate, and microfauna were determined as the important factors for the reduction of excess sludge. The study revealed that, with the excellent oxygen supply system of the DHS configuration, the DHS sludge has sufficient characteristics in terms of high concentration, relatively high endogenous respiration rate, and significantly high density and diversity of microfauna to minimize excess sludge production.

\section{Acknowledgements}

This study was supported by research grants from the New Energy and Industrial Technology Development Organization (NEDO), the Ministry of Education, Culture, Sports, Science and Technology (MEXT), and SATREPS, JST/JICA, Japan.

\section{References}

1. APHA, 1998. Standard Methods for the Examination of Water and Wastewater, 20th edition, APHA/AWWA/WEF. 
2. Abbassi, B., Dullstein, S., Rabiger N., 2000. Minimization of excess sludge production by increase of oxygen concentration in activated sludge flocs; experimental and theoretical approach. Water Res. 34(1), 139-146.

3. Araki, N., Ohashi, A., Machdar, I., Harada, H., 1999. Behaviors of nitrifiers in a novel biofilm reactor employing hanging sponge-cubes as attachment site. Wat. Sci. Technol. 39(7), 23-31.

4. Castillo, A., Cecchi, F., Mata-alvarez, J., 1997. A combined anaerobic-aerobic system to treat domestic sewage in coastal areas. Water Res. 31(12), 3057-3063.

5. Cavalcanti, P.F.F., Medeiros, E.J.S., Silva, J.K.M., Van Haandel, A., 1999. Excess sludge discharge frequency for UASB reactors. Water Sci. Technol. 40(8), 211-219.

6. Chang, C-Y., Tanong, K., Chiemchaisri, C., Vigneswaran, S., 2011. Feasibility study of a cyclic anoxic/aerobic two-stage MBR for treating ABS resin manufacturing wastewater. Bioresour. Technol., 102(9), 5325-5330.

7. Elissen, H.J.H., Hendrickx, T.L.G., Temmink, H., Buisman, C.J.N., 2006. A new reactor concept for sludge reduction using aquatic worms. Water Res. 40(20), 3713-3718.

8. Gonçalves, R.F., Araujo, V.L.D., Chernicharo, C.A.L., 1998. Association of a UASB reactor and a submerged aerated biofilter for domestic sewage treatment. Water Sci. Technol. 38(8-9), 189-195.

9. Hendrickx T.L.G., Temmink, H., Elissen, H.J.H., Buisman, C.J.N., 2009. The effect of operating conditions on aquatic worms eating waste sludge. Water Res. 43(4), 943-950.

10. Huang, X., Liang, P., Qian, Y., 2007. Excess sludge reduction induced by Tubifex tubifex in a recycled sludge reactor. J. Biotechnol. 127(3), 443-451.

11. Kassab, G., Halalsheh, M., Klapwijk, A., Fayyad, M., van Lier, J.B., 2010. 
Sequential anaerobic-aerobic treatment for domestic wastewater - A review. Bioresour. Technol. 101, 3299-3310.

12. Khursheed, A., Kazmi, A.A., 2011. Retrospective of ecological approaches to excess sludge reduction. Water Res. 45(15), 4287-4310.

13. Kristensen G.H., Jorgensen P.E., Henze M., 1992. Characterization of functional microorganism groups and substrate in activated sludge and wastewater by AUR, NUR, and OUR. Water Sci. Technol. 25(6), 43-57.

14. Lettinga, G., Roersma, R., Grin, P., 1983. Anaerobic treatment of raw domestic sewage at ambient temperatures using a granular bed UASB reactor. Biotechnol. Bioeng. 25, 1701-1723.

15. Liang, P., Huang, X., Qian, Y., Wei, Y., Ding, G. 2006. Determination and comparison of sludge reduction rates caused by microfaunas' predation. Bioresour. Technol, 97(6), 854-861.

16. Low, E.W., Chase, H.A., 1999. The effect of maintenance energy requirements on biomass production during wastewater treatment. Water Res. 33(3), 847-853.

17. Luxmy, B.S., Kubo, T., Yamamoto, K., 2001. Sludge reduction potential of metazoa in membrane bioreactos. Water Sci. Technol. 44(10), 197-202.

18. Machdar, I., Sekiguchi, Y., Sumino, H., Ohashi, A. Harada, H., 2000. Combination of a UASB reactor and a curtain type DHS (downflow hanging sponge) reactor as a cost-effective sewage treatment system for developing countries. Water Sci. Technol. $42(3-4), 83-88$.

19. McCarty P.L., 1964. Anaerobic wastetreatment fundamentals. Public Works, September, 107-112.

20. Phan, I. Q. H., Pilbout, S. F., Fleischmann, W., Bairoch, A., 2003. NEWT, a new taxonomy portal. Nucleic Acids Res. 31(13), 3822-3823. 
21. Rensink, J.H., Rulkens, W.H., 1997. Using metazoa to reduce sludge production. Water Sci. Technol. 36(11), 171-179.

22. Sato, N., Okubo, T., Onodera, T., Ohashi, A. Harada, H., 2006. Prospects for a self-sustainable sewage treatment system: A case study on full-scale UASB system in India's Yamuna River Basin. J. Environ. Manag. 80, 198-207.

23. Sun, D.D., Khor, S.L., Hay, C.T., Leckie, J.O., 2007. Impact of prolonged sludge retention time on the performance of a submerged membrane bioreactor. Desalination 208(1-3), 101-112.

24. Takahashi, M., Ohya, A., Kawakami, S., Yoneyama, Y., Onodera, T., Syutsubo, K., Yamazaki, S., Araki, N., Ohashi, A., Harada, H. Yamaguchi, T. 2011. Evaluation of treatment characteristics and sludge properties in a UASB reactor treating municipal sewage at ambient temperature. Int. J. Environ. Res. 5(4), 821-826.

25. Tandukar, M., Uemura, S., Ohashi, A., Harada, H., 2005. A low-cost municipal sewage treatment system with a combination of UASB and the "fourth-generation" downflow hanging sponge reactors. Water Sci. Technol. 52(1-2), 323-329.

26. Tandukar, M., Uemura, S., Ohashi, A., Harada, H., 2006. Combining UASB and the "fourth generation" down-flow hanging sponge reactor for municipal wastewater treatment. Water Sci. Technol. 53(3), 209-218.

27. Tandukar M., Ohashi A., Harada H. 2007. Performance comparison of a pilot-scale UASB and DHS system and activated sludge process for the treatment of municipal wastewater. Water Res. 41, 2697-2705.

28. Tawfik, A., Ohashi, A. Harada, H., 2006. Sewage treatment in a combined up-flow anaerobic sludge blanket (UASB)-down-flow hanging sponge (DHS) system.

Biochem. Eng. J. 29, 210-219.

29. Troiani, C., Eusebi, A.L., Battistoni, P., 2011. Excess sludge reduction by 
biological way: From experimental experience to a real full scale application. Bioresour. Technol. 102(22), 10352-10358.

30. Wei, Y., Van Houten, R.T., Borger, A.R., Eikelboom, D.H., Fan Y., 2003 a. Minimization of excess sludge production for biological wastewater treatment. Water Res. 37(18), 4453-4467.

31. Wei, Y., Van Houten, R.T., Borger, A.R., Eikelboom, D.H., Fan Y., 2003 b. Comparison performances of membrane bioreactor and conventional activated sludge processes on sludge reduction induced by Oligochaete. Environ. Sci. Technol. 37(14), 3171-3180.

32. Wei, Y., Wang, Y., Guo, X., Liu, J., 2009. Sludge reduction potential of the activated sludge process by integrating an oligochaete reactor. J. Hazard. Mater. 163(1), 87-91.

33. Witzig R., Manz W., Rosenberger S., Kruger U., Kraume M., Szewzyk U., 2002. Microbiological aspects of a bioreactor with submerged membranes for aerobic treatment of municipal wastewater. Water Res. 36, 394-402.

34. Yoon, S-H., Kim, H-S., Yeom, I-T., 2004. The optimum operational condition of membrane bioreactor (MBR): cost estimation of aeration and sludge treatment. Water Res. 38, 37-46.

35. Zhou, K., Xu, M., Dai, J., Cao, H., 2006. The microfauna communities and operational monitoring of an activated sludge plant in China. European J. Protistol. 42(4), 291-295. 
Table 1. Summary of effluent quality in the system between day 446 and day 810 .

\begin{tabular}{|c|c|c|c|}
\hline & Sewage & UASB eff. & DHS eff. \\
\hline $\mathrm{SS}, \mathrm{mg} \mathrm{L}^{-1}$ & $95(25)$ & $33(21)$ & $12(12)$ \\
\hline $\mathrm{VSS}, \mathrm{mg} \mathrm{L}^{-1}$ & $83(22)$ & $28(18)$ & $9(9)$ \\
\hline Unfiltered BOD, $\mathrm{mg} \mathrm{L}^{-1}$ & $183(63)$ & $53(23)$ & $7(4)$ \\
\hline Unfiltered $\mathrm{COD}_{\mathrm{Cr}}, \mathrm{mg} \mathrm{L}^{-1}$ & $292(64)$ & $113(36)$ & $36(22)$ \\
\hline Filtered $\mathrm{COD}_{\mathrm{Cr}}, \mathrm{mg} \mathrm{L}^{-1}$ & $143(34)$ & $56(12)$ & $23(9)$ \\
\hline $\mathrm{TKN}, \mathrm{mg} \mathrm{L}^{-1}$ & $31(4)$ & $30(4)$ & $3(3)$ \\
\hline $\mathrm{NH}_{4}-\mathrm{N}, \mathrm{mg} \mathrm{L}^{-1}$ & $22(3)$ & $27(3)$ & $3(4)$ \\
\hline $\mathrm{NO}_{3}-\mathrm{N}, \mathrm{mg} \mathrm{L}^{-1}$ & N.D. & N.D. & $18(4)$ \\
\hline $\mathrm{NO}_{2}-\mathrm{N}, \mathrm{mg} \mathrm{L}^{-1}$ & N.D. & N.D. & N.D. \\
\hline $\mathrm{DO}, \mathrm{mg} \mathrm{L}^{-1}$ & N.D. & N.D. & $6.6(0.7)$ \\
\hline
\end{tabular}

Numbers in parenthesis are standard deviation,

N.D. $=$ Not detectable 
Table 2. Comparison of the excess sludge production with conventional treatment processes.

\begin{tabular}{|c|c|c|c|c|c|c|c|c|c|}
\hline \multirow{4}{*}{ Treatment system } & \multirow{4}{*}{ Wastewater } & \multirow{3}{*}{ HRT } & \multirow{3}{*}{ SRT } & \multirow{3}{*}{ Temp. } & \multirow[t]{2}{*}{ Sludge } & \multirow[t]{2}{*}{ Volumetric } & \multirow[t]{2}{*}{ COD-VSS } & \multicolumn{2}{|l|}{ Excess sludge } \\
\hline & & & & & & & & & \\
\hline & & & & & concentration & OLR & loading rate & production & Reference \\
\hline & & $\mathrm{h}$ & day & ${ }^{\circ} \mathrm{C}$ & $\mathrm{g} \mathrm{VSS} \mathrm{L}^{-1}$ & $\mathrm{~kg} \mathrm{COD} \mathrm{m}^{-3}$ day $^{-1}$ & $\mathrm{~kg} \mathrm{COD} \mathrm{kg}^{-1} \mathrm{VSS}_{\text {day }}{ }^{-1}$ & $\mathrm{~g} \mathrm{SS} \mathrm{g}^{-1}$ COD removed & \\
\hline ASP & Sewage & 12 & $3-5$ & $9-32$ & 1.4 & 2.3 & 1.7 & 0.88 & Tandukar et al., 2007 \\
\hline UASB & Sewage & 4 & 45 & 28 & 13 & 3.5 & 0.27 & 0.15 & Cavalcanti et al., 1999 \\
\hline SMBR & Industrial & 8 & 200 & 25 & $12-15$ & 3 & 0.11 & $0.115 \dagger$ & Sun et al., 2007 \\
\hline STMBR & Artificial & 6 & $20-40$ & - & $10-15$ & - & - & $0.23-0.32$ & Yoon et al., 2004 \\
\hline $\mathrm{RBC}$ & Sewage (UASB eff.) & 0.75 & - & 18 & - & $1.36^{* *}$ & - & $0.29-0.33 \dagger \dagger$ & Castillo et al., 1997 \\
\hline SABF & Sewage (UASB eff.) & 0.17 & - & - & - & $>5.0(>1.2 *)$ & - & 0.37 & Goncalves et al., 1998 \\
\hline DHS & Sewage (UASB eff.) & 3.2 & $>135$ & $10-28$ & 27 & $0.85\left(0.43^{*}\right)$ & $0.03(0.02 * * *)$ & $0.09(0.07 \dagger \dagger)$ & This study \\
\hline
\end{tabular}

ASP: Activated sludge process, UASB: Upflow anaerobic sludge blanket, SMBR: Submerged membrane bioreactor, STMBR: Separated type membrane bioreactor, RBC: Rotating biological contactor,

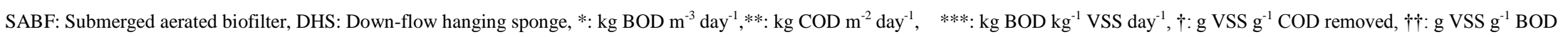

removed. RBC, SABF and DHS are post treatment processes of UASB treating sewage. 


\section{Figure captions}

Fig. 1. Time courses of (A) temperature, (B) SS and (C) BOD during the entire operation period.

Fig. 2. Change in the retained sludge concentration during the entire operational period. The arrows indicate the profile results in Fig. 3.

Fig. 3. Profile of the sludge concentration in the DHS reactor.

Fig. 4. The numbers of microfauna in the DHS sludge.

*The black and white figure will be supplied for the printed version. 
Fig. 1. Time courses of (A) temperature, (B) SS and (C) BOD of the entire operational period.
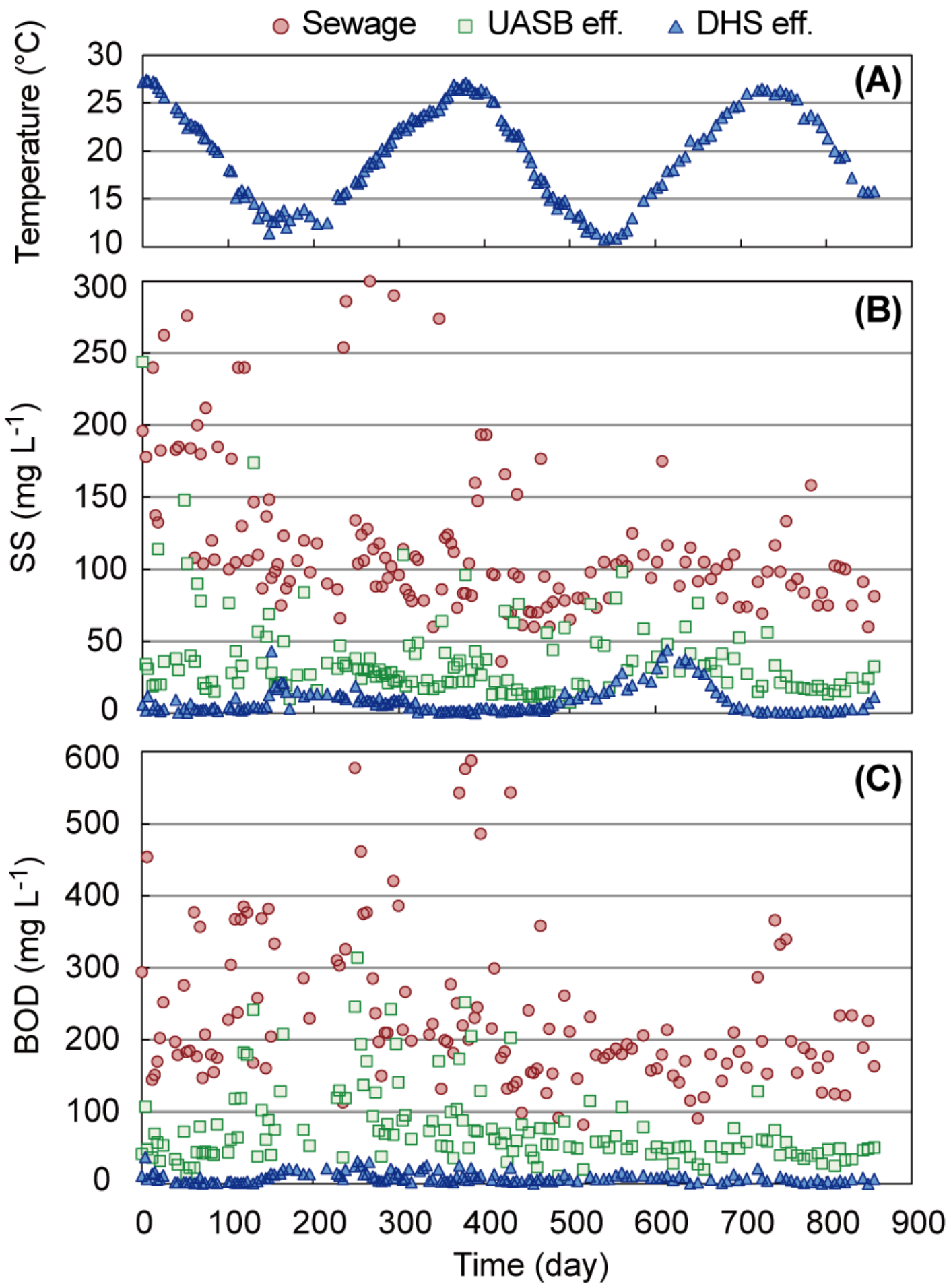
Fig. 2. Change in the retained sludge concentration during the entire operational period. The arrows indicate the dates in which the sludge profile data was obtained as shown in Fig. 3.

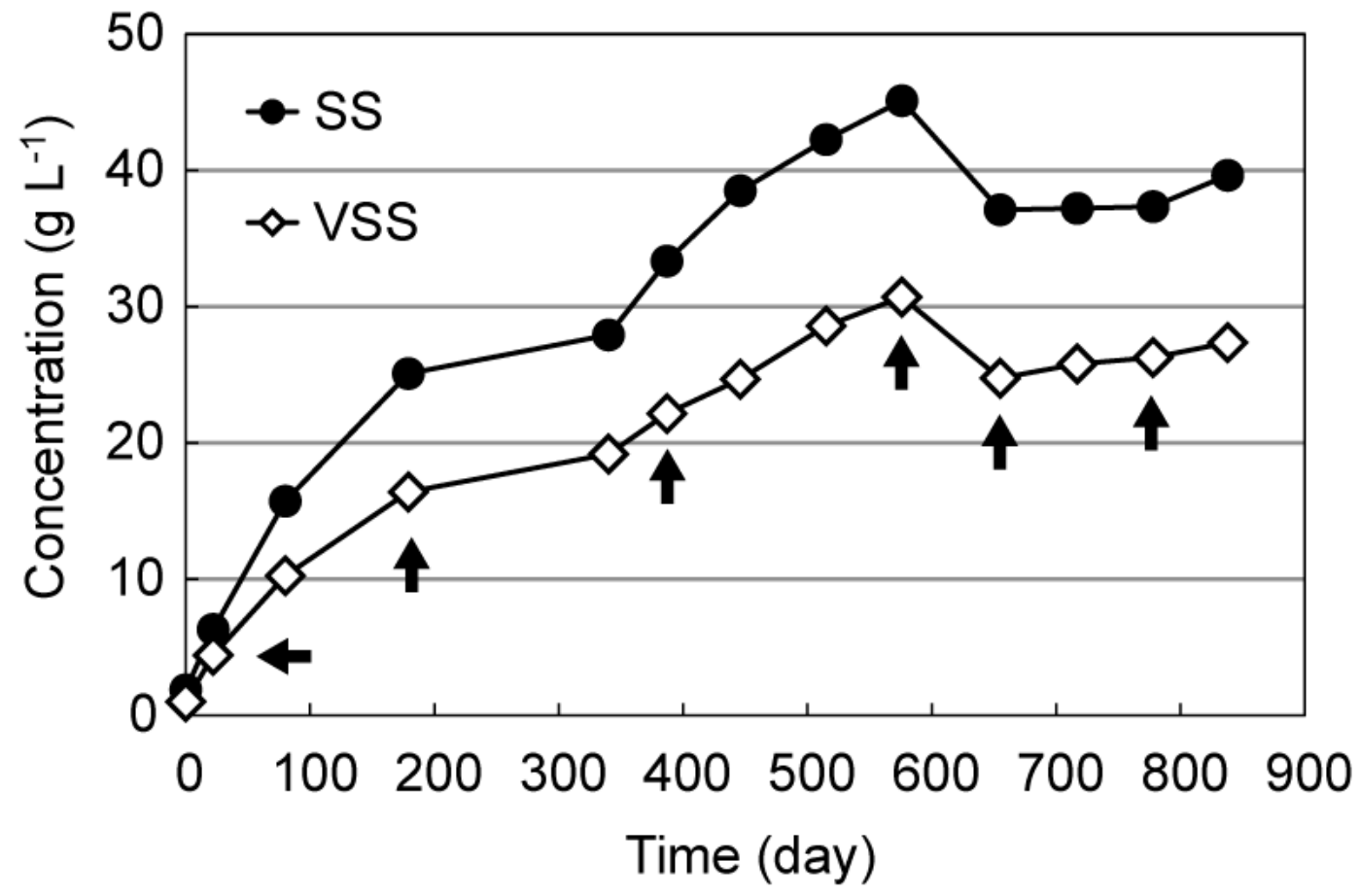


Fig. 3. Profile of the sludge concentration in the DHS reactor.

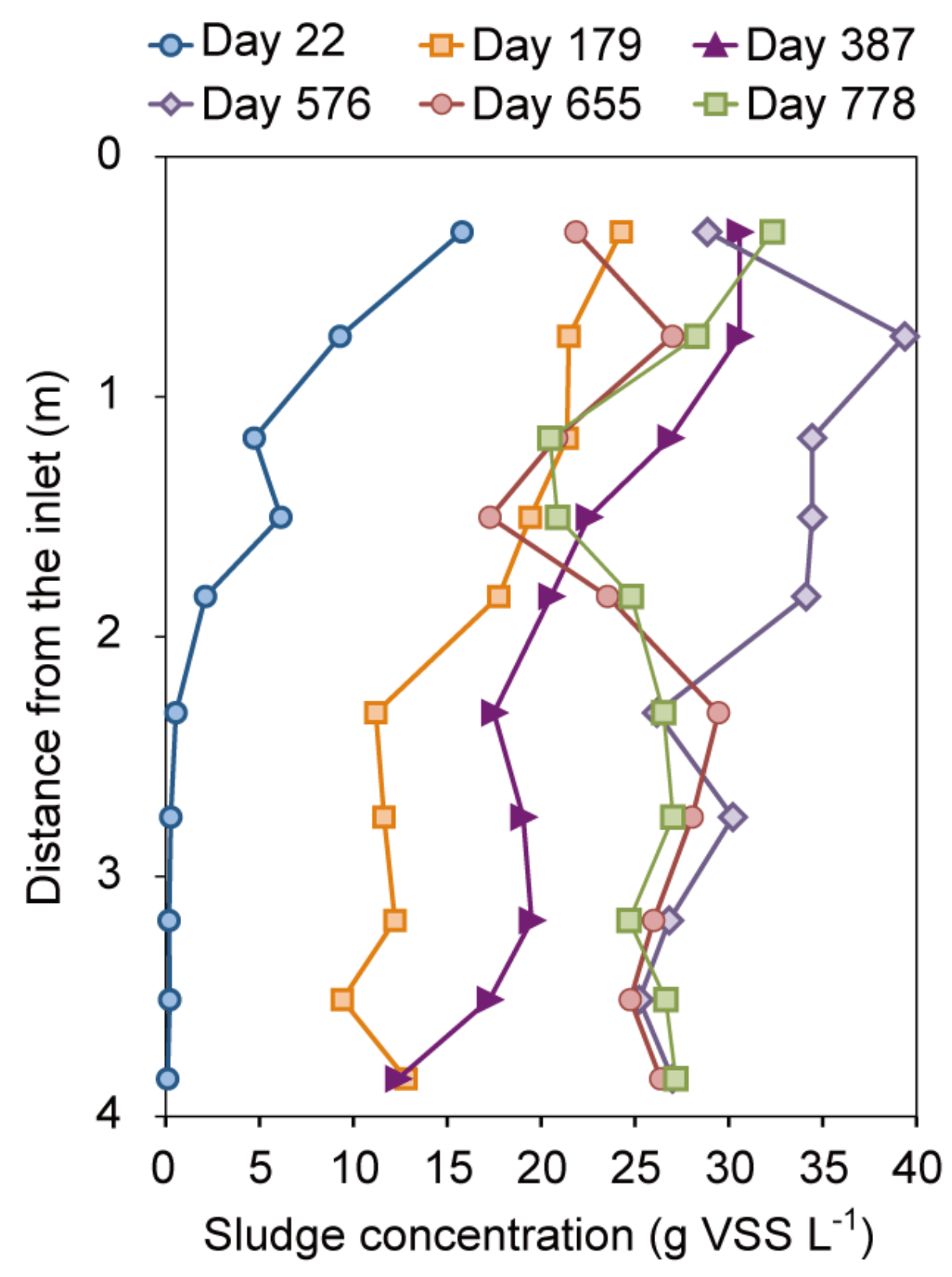


Fig. 4. Numbers of microfauna in the DHS sludge.

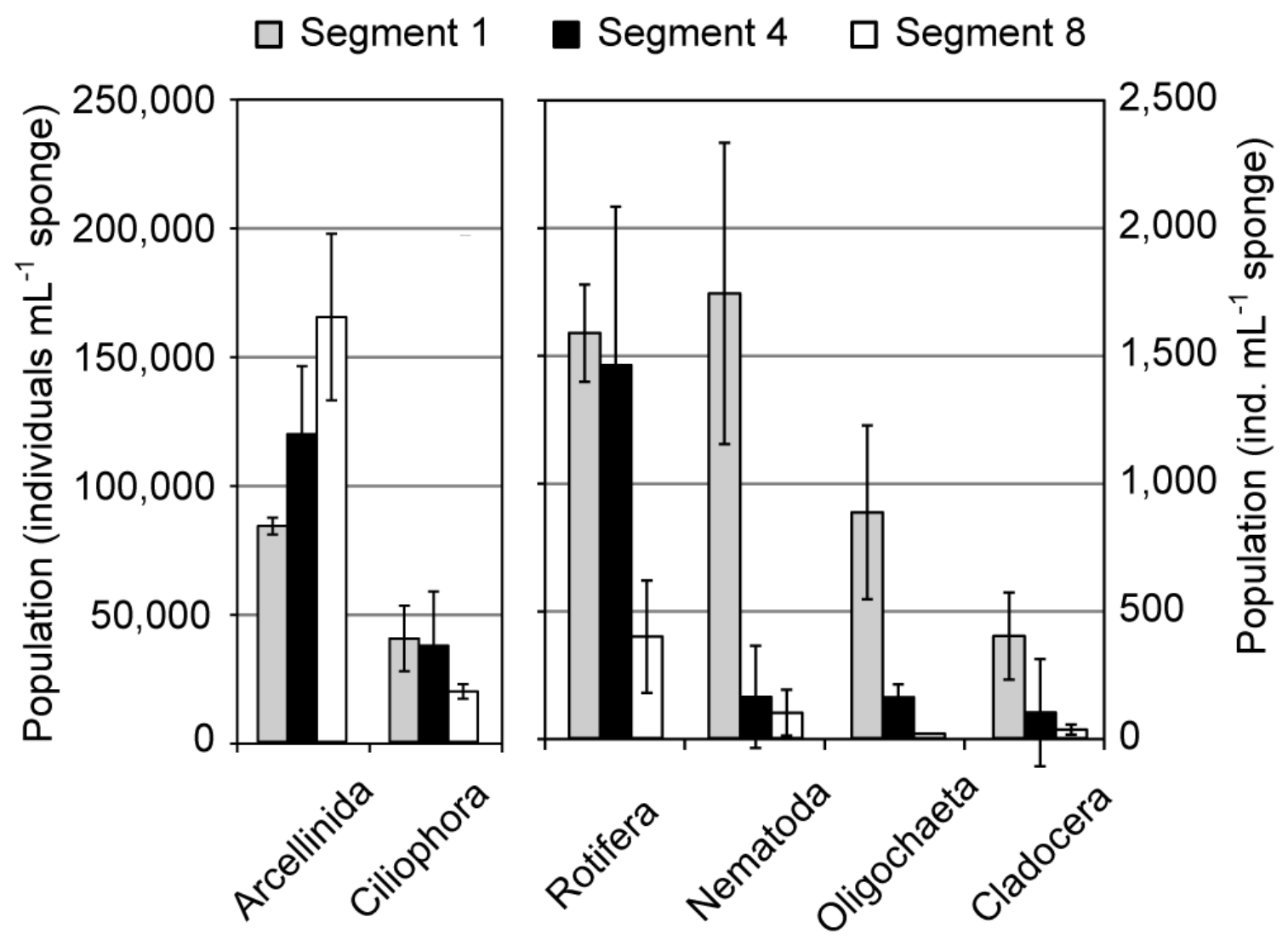

